\title{
CLONING AND ANALYSIS OF A GENE (SMS13) ENCODING SANNAMYCIN B- GLYCYLTRANSFERASE FROM Streptomyces sannanensis AND ITS DISTRIBUTION AMONG ACTINOMYCETES
}

\author{
Toshio Ohta, Eri Hashimoto and Mamoru Hasegawa \\ Tokyo Research Laboratories, Kyowa Hakko Kogyo Co., Ltd., \\ 3-6-6 Asahi-machi, Machida-shi, Tokyo 194, Japan \\ (Received for publication December 19, 1991)
}

\begin{abstract}
A gene encoding sannamycin B-glycyltransferase (smsl3) of Streptomyces sannanensis IFO 14239 was identified by cloning and complementation of $S$. sannanensis mutant SN13 which is blocked at the interconversion of sannamycins B and A. The cloned DNA fragment also permitted the conversion of fortimicin B to A both in S. sannanensis SN13 and Streptomyces lividans TK23. DNA sequences similar to sms 13 were detected in all five producers of the fortimicin-group antibiotics, Micromonospora olivasterospora ATCC 21819 (fortimicin-producer), Micromonospora sp. strain SF-2098 ATCC 31580 (SF-2052), Dactylosporangium matsuzakiense ATCC 31570 (dactimicin), Streptomyces tenjimariensis ATCC 31603 (istamycin), and Saccharopolyspora hirsuta ATCC 20501 (sporaricin). This suggests that these genes of similar function from different genera were derived from a common ancestral gene.
\end{abstract}

Antibiotics with similar structures are often produced by taxonomically distant microorganisms, and the sequences of such antibiotic biosynthetic genes are well conserved, e.g. in polyketide antibiotics ${ }^{1)}$ and in $\beta$-lactam antibiotics ${ }^{2 \sim 5}$; this is of considerable interest from the point of view of the evolution and distribution of the secondary metabolic pathways. Fortimicin A (astromicin) ${ }^{6}$ produced by Micromonospora olivasterospora ATCC 21819, has an unique pseudodisaccharide structure. A number of other fortimicin-group antibiotics of similar structures are known, which are produced by the following five members of four different genera; Streptomyces sannanensis IFO 14239 (sannamycin) ${ }^{7}$, Streptomyces tenjimariensis ATCC 31603 (istamycin) ${ }^{8)}$, Saccharopolyspora hirsuta ATCC 20501 (sporaricin) ${ }^{9)}$, Micromonospora sp. SF-2098 ATCC 31580 (SF-2052 compounds) ${ }^{10)}$ and Dactylosporangium matsuzakiense ATCC 31570 (dactimicins) $^{11)}$.

The biosynthetic pathway of fortimicin A in $M$. olivasterospora is believed to consist of more than 14 steps $^{12)}$. All members of the fortimicin-group antibiotics are thought to be synthesized by related biosynthetic pathways ${ }^{13,14)}$. It is unlikely that such complex biosynthetic routes evolved by chance independently in different genera, and dissemination of these antibiotic productivities by some form of

Fig. 1. Proposed reaction of sannamycin B to sannamycin A in Streptomyces sannanensis IFO 14239.

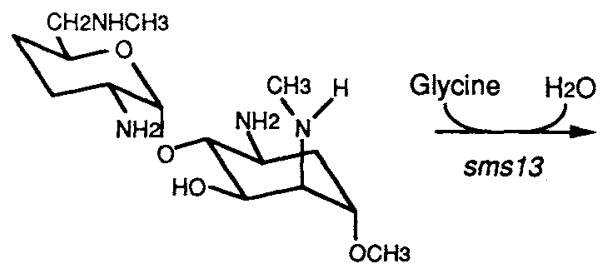

sannamycin B

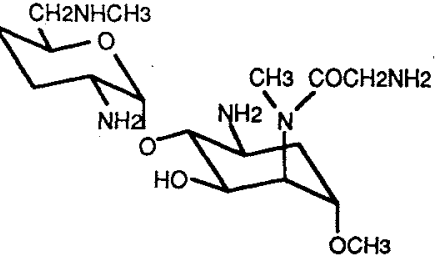

sannamycin A 
the horizontal transfer could be considered. We have previously reported a self-cloning system in S. sannanensis ${ }^{15}$ ) and also obtained nonproducing mutants by mutagenesis ${ }^{16)}$. In this study, we cloned the sannamycin B-glycyltransferase gene by complementation in the nonproducing mutant $S$. sannanensis SN13, which was blocked at the conversion of sannamycin B to A (Fig. 1). A study of the distribution of sequences similar to sms 13 in other actinomycetes is presented.

\section{Materials and Methods}

Bacterial Strains and Plasmids

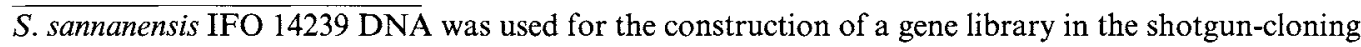
of sms13. S. sannanensis SN13, blocked at sannamycin B-glycyltransferase $\operatorname{step}^{16)}$, was used as a host. S. lividans TK23 was employed to assay the fortimicin B to A converting activity by sms 13 . Either Bacillus subtilis ATCC 6633 or Escherichia coli ATCC 26 were used as indicators for antibacterial activity. Plasmid pEN101 ${ }^{17)}$ was used as a plasmid vector for S. sannanensis cloning.

\section{Cultivation Conditions}

S. lividans strains were grown in SK No. 2 medium at $30^{\circ} \mathrm{C}$ for 3 days. SK No. 2 medium consisted of Stabilose K (Matsutani Kagaku) 2.0\% (w/v), glucose 0.5\%, yeast extract (Nippon Seiyaku) $0.5 \%$, peptone (Nippon Seiyaku) 0.5\%, meat extract (Kyokuto Seiyaku) $0.3 \%, \mathrm{KH}_{2} \mathrm{PO}_{4} 0.02 \%, \mathrm{MgSO}_{4} \cdot 7 \mathrm{H}_{2} \mathrm{O}$ $0.06 \%, \mathrm{pH}$ 7.6. S. sannanensis strains were grown in $\mathrm{SA}$ medium ${ }^{16)}$ at $30^{\circ} \mathrm{C}$ for 3 days. For strains harboring pEN101 or its derivatives, $2 \mu \mathrm{g} / \mathrm{ml}$ of thiopeptin (Fujisawa) was added.

Protoplasting and Transformation

Protoplasting and transformation were carried out according to the method described for S. sannanensis IFO $14239^{15)}$. Protoplasting and transformation of $S$. lividans were according to CHATER et $a{ }^{18}{ }^{18}$.

Preparation and Manipulation of DNA

Genomic DNA was isolated as described by CHATER et al. ${ }^{18)}$. Plasmid DNA was isolated according to KIESER ${ }^{19}$. Restriction endonucleases, calf intestine alkaline phosphatase and T4 DNA ligase (Boehringer or Takara) were used under the conditions specified by the suppliers.

Shotgun-cloning and Subcloning of sms 13

Total DNA $(300 \mu \mathrm{g})$ prepared from S. sannanensis IFO 14239 was partially digested with Sau3A I and size-fractionated by $10 \sim 40 \%$ sucrose density gradient ultracentrifugation to obtain $4 \sim 6 \mathrm{~kb}$ DNA fragments. Plasmid pEN101 prepared from $S$. sannanensis $(10 \mu \mathrm{g})$ was completely digested with $B g l$ II and dephosphorylated with calf intestine alkaline phosphatase. The digested genomic DNA $(22 \mu \mathrm{g})$ and vector DNA $(10 \mu \mathrm{g})$ were ligated with T4 DNA ligase at $16^{\circ} \mathrm{C}$ for 15 hours and transformed into $S$. sannanensis SN13 as described above. Thiopeptin-resistant transformants were incubated at $30^{\circ} \mathrm{C}$ for 6 days in SA medium containing $2 \mu \mathrm{g} / \mathrm{ml}$ of thiopeptin, and the colonies were overlaid with $\mathrm{E}$ medium ${ }^{16}$ ) containing $10^{5} \mathrm{cells} / \mathrm{ml}$ of $E$. coli ATCC 26 and incubated at $37^{\circ} \mathrm{C}$ for 16 hours. Transformants which formed inhibitory zones were transferred to SY2 medium ${ }^{16)}$ containing $50 \mu \mathrm{g} / \mathrm{ml}$ of fortimicin A and incubated at $30^{\circ} \mathrm{C}$ for 3 days to eliminate $E$. coli.

Plasmid pSN13-1, obtained in the shotgun-cloning, was completely digested with EcoR I, and dephosphorylated with alkaline phosphatase. Subsequently, it was partially digested with Sau3A I and ligated with pEN101 cut by Bgl II. S. sannanensis SN13 was transformed with this DNA and the transformants restoring sannamycin A production were obtained. Plasmid containing insertion fragments smaller than that of pSN13-1 were selected.

Construction of pSN13-1-8T Carrying sms 13 and a Fortimicin-resistance Gene

A scheme for the formation of pSN13-1-8T carrying both sms 13 and a fortimicin-resistance gene was 
shown in Fig. 2. Plasmid pSN13-1-8 which was obtained by subcloning was partially digested with $B c l$ I and ligated to the $1.5 \mathrm{~kb} \mathrm{BamH} \mathrm{I}$ fragment of $\mathrm{pFMRT}{ }^{20)}$ containing the fortimicin A-resistance gene $(f m r T)$ cloned from $S$. tenjimariensis ATCC 31603. S. lividans TK23 was transformed with this DNA preparation. Thiopeptin-resistant transformants were transferred onto ATCC No. 5 medium containing neomycin B at $50 \mu \mathrm{g} / \mathrm{ml}$ to select the transformants harboring fmrT. S. lividans TK23 (pSN13-1-8T) carrying both sms 13 and $f m r T$ was selected from these transformants by determination of the physical

Fig. 2. Construction scheme of pSN13-1-8T.

The DNA fragments containing sms 13, fmrT and its flanking sequence are represented by filled, dotted and open boxes, respectively.

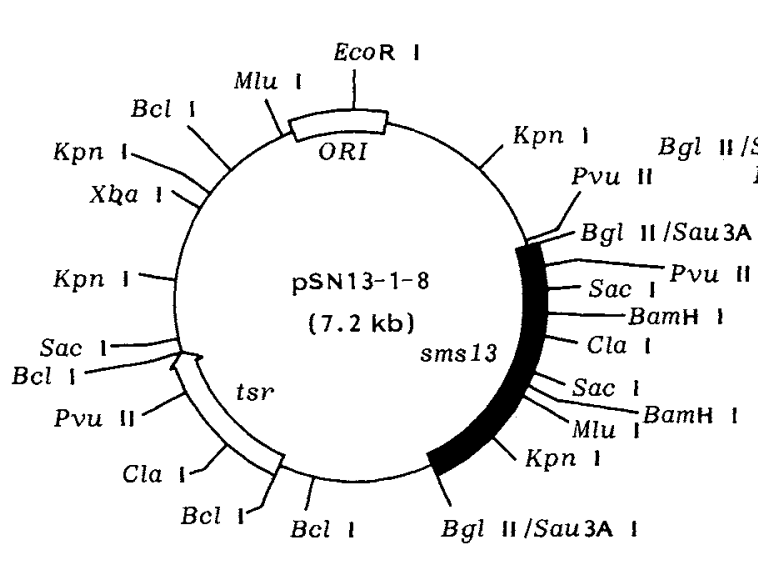

Bcl I partial digestion

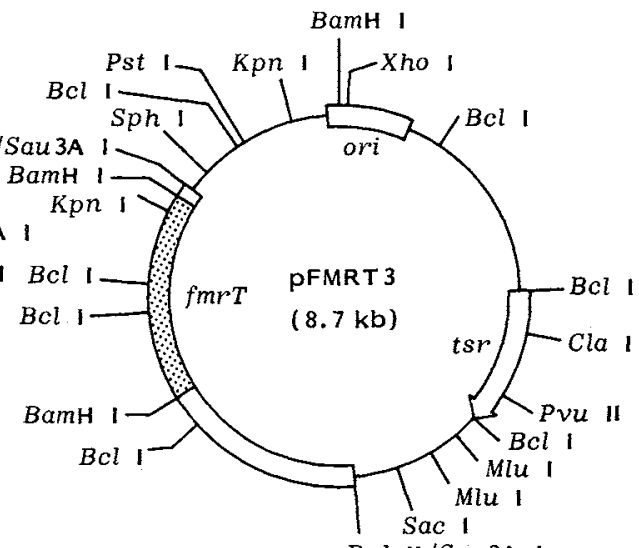

Bgl II/Sau 3A I

BamH | digestion

$\sim 7 \mathrm{~kb}$ fragment

$1.5 \mathrm{~kb}$ fragment

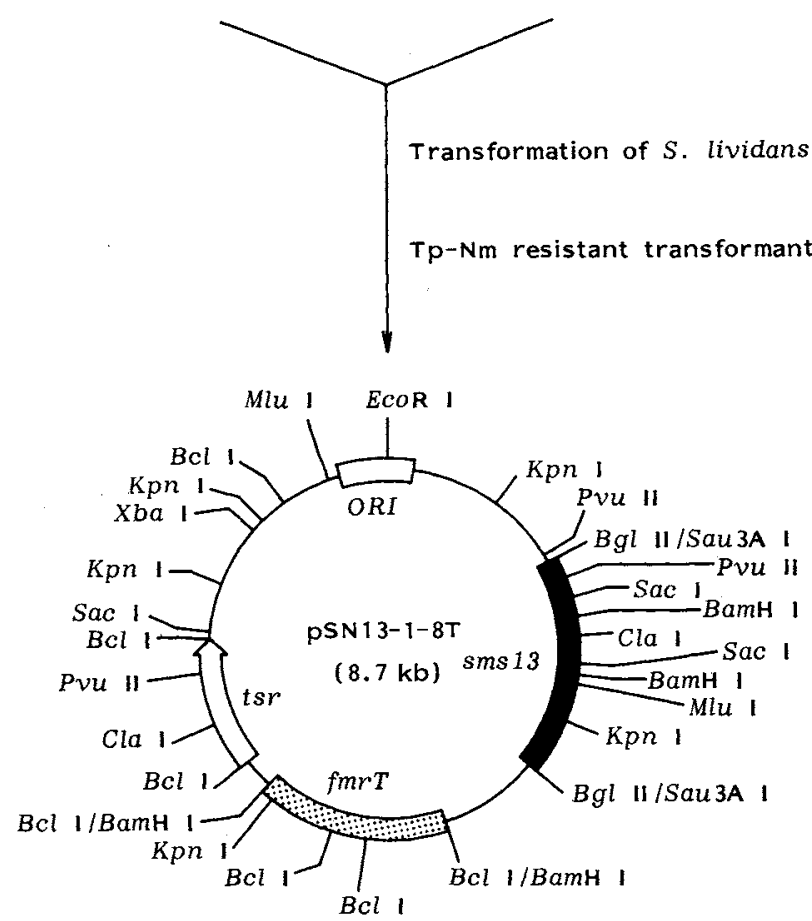


maps of the harbored plasmids.

\section{Detection of Fortimicin B to Fortimicin A Converting Activity}

Activity of sannamycin B-glycyltransferase in the washed mycelia was examined using fortimicin $\mathrm{B}$ as substrate according to DAIRI and HASEGAWA ${ }^{13)}$. The products were detected by HPLC ${ }^{13)}$.

\section{Alkaline Treatment of the Bioconversion Products of Fortimicin B}

The fortimicin B-bioconverted products by the washed mycelia of S. lividans TK23 (pSN13-1-8T) were treated in $0.16 \mathrm{M} \mathrm{NH}_{4} \mathrm{OH}$ or $0.16 \mathrm{~N} \mathrm{NaOH}$ at room temperature for an hour and analyzed by using HPLC after neutrization with $\mathrm{H}_{2} \mathrm{SO}_{4}$.

\section{Southern-blot Hybridization}

Total DNAs isolated from various actinomycetes were digested with Bam $\mathrm{H} \mathrm{I}$ and separated in $0.7 \%$ agarose gel electrophoresis. They were blotted to Genescreen plus (NEN) by the alkaline transfer method $^{21)}$. The $0.8 \mathrm{~kb}$ Sal I fragment of pSN13-1 was labeled with $\alpha-{ }^{32} \mathrm{P}-\mathrm{dCTP}$ (Amersham) by nick-translation. Hybridization was performed at $65^{\circ} \mathrm{C}$ for 16 hours in a hybridization solution consisting of $6 \times \mathrm{SSC}^{22)}, 5 \times$ DENHARDT's solution ${ }^{22)}, 100 \mu \mathrm{g} / \mathrm{ml}$ sonicated and denatured calf thymus DNA, with the radioactive DNA probe. Filters were washed twice at room temperature in $150 \mathrm{ml}$ of $0.5 \times \mathrm{SSC}-0.2 \%$ SDS for 15 minutes, and four times at $65^{\circ} \mathrm{C}$ in $250 \mathrm{ml}$ of $0.3 \times \mathrm{SSC}-0.2 \% \mathrm{SDS}$ for 30 minutes. After drying, the filters were exposed to $\mathrm{X}$-ray film (Fuji) at $-80^{\circ} \mathrm{C}$ for $1 \sim 2$ days.

\section{Results}

\section{Cloning of $s m s 13$}

Glycylation of fortimicin B and sannamycin B (Fig. 1) are required to convert these antibiotics to biologically active molecules ${ }^{6}$. This amino acid transfer is an interesting characteristic of the biosynthesis of the fortimicin-group antibiotics. We have obtained the gene encoding the enzyme for this step by using S. sannanensis SN13, a mutant deficient in sannamycin B-glycyltransferase, as the host for cloning. Two transformants which restored antibiotic production were obtained from 6,126 thiopeptin-resistant transformants. These plasmids were designated pSN13-1 and pSN13-2, respectively (Fig. $3 \mathrm{a}$ ). A $2.7 \mathrm{~kb}$ overlapping region was observed in the inserts of the two plasmids. On subsequent subcloning, we obtained three types of plasmids from pSN13-1. Physical maps of their DNA inserts are shown in Fig. $3 \mathrm{~b}$. Plasmid pSN13-1-8 contained a minimum $1.3 \mathrm{~kb}$ fragment which was common to the inserts of pSN13-1 and pSN13-2; S. sannanensis SN13 (pSN13-1-8) restored sannamycin A production. Thus, sms 13 could be located within this $1.3 \mathrm{~kb}$. Fortimicin B to A converting activity was restored in the bioconversion using the washed mycelia of S. sannanensis SN13 (pSN13-1) (Fig. 4, a c). Activity was also detected in the washed mycelia of $S$. lividans TK23 (pSN13-1-8T) harboring sms13 together with the fortimicin-resistance gene $(f m r T)^{20)}$ of S. tenjimariensis ATCC 31603 (Fig. 4, d e). We also observed an unknown product at a retention time very close to that of $N$-formimidoylfortimicin A during HPLC analysis of the bioconverted products by $S$. lividans TK23 (pSN13-1-8T). However, it was not $N$-formimidoylfortimicin A because the peak was stable to alkaline treatment under conditions in which $N$-formimidoylfortimicin A was degradated to fortimicin A (Fig. 4 f). Thus, we concluded that the sms 13 gene product converted fortimicin B directly to fotimicin A.

\section{Distribution of sms13-like Sequences in Actinomycetes}

Southern-blot analysis was performed using the $0.8 \mathrm{~kb}$ SalI fragment of pSN18-1-8 (Fig. $3 \mathrm{~b}$ ) as a probe. Two signals, 0.8 and $0.55 \mathrm{~kb}$, were detected in BamH I-digested S. sannanensis DNA in agreement 
Fig. 3. The physical maps of the cloned fragments containing sms13.

Inserted DNA fragments of pSN13-1, pSN13-2 (a) and the subcloned plasmids (b) are shown. Open box represents the proposal region of sms 13 . Thick bar represents the $0.8 \mathrm{~kb}$ Sal 1 fragment which was used as a probe in Southern blot hybridization analysis.

(a)

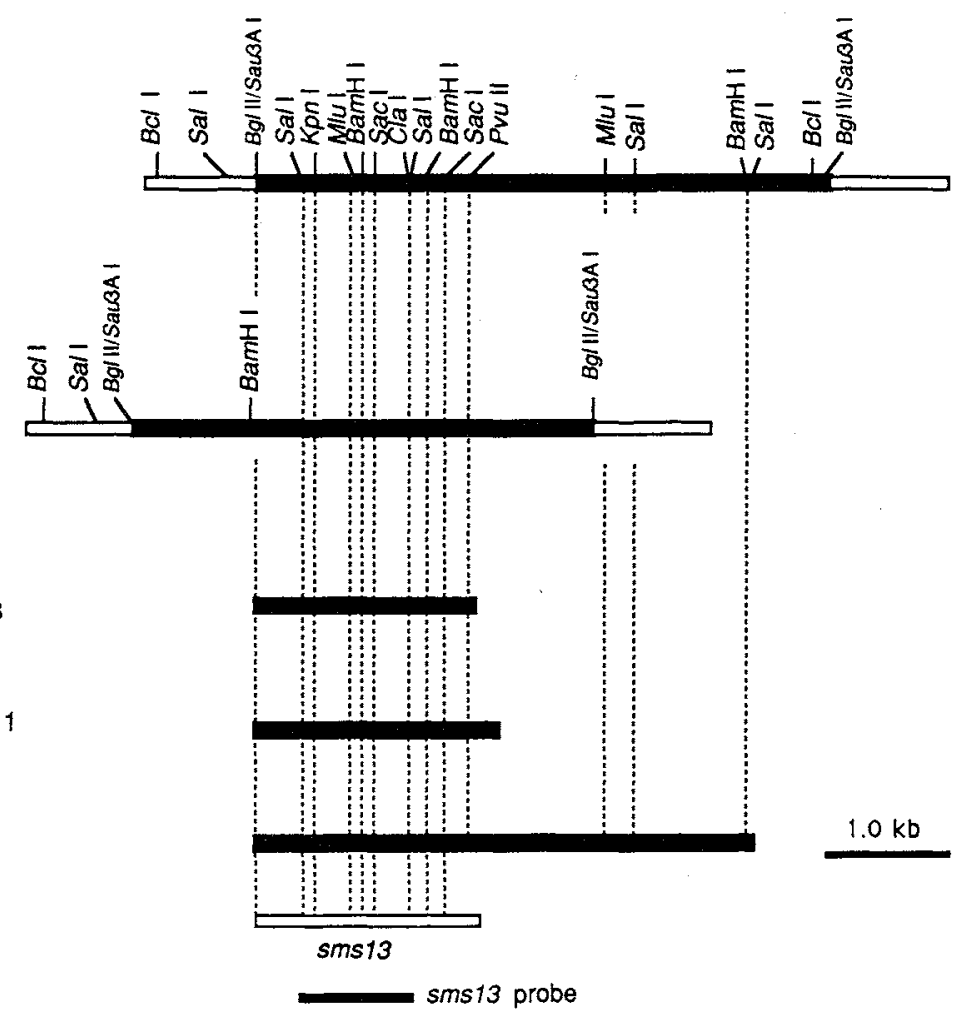

(b)

pSN13-1

with the structure of pSN13-1 and pSN13-2 (Fig. 5). Positive signals of different size $(0.6$ to $6.0 \mathrm{~kb})$ were detected in all the producers of fortimicin-group antibiotics. DNA homologous to sms 13 detected in $M$. olivasterospora is present in the gene cluster for fortimicin biosynthesis (DAIRI et al.; in preparation). The size of the DNA fragment detected in $M$. olivasterospora $(6.0 \mathrm{~kb} B a m \mathrm{H} \mathrm{I}$ fragment $)$ agreed with the organization of the gene cluster, which might encode fortimicin B-glycyltransferase ( $m$ ms 13). Analyses in which the genomic DNAs were digested with several restriction enzymes revealed significant conservation between $M$. olivasterospora and Micromonospora sp. SF-2098, independently isolated (data not shown). Under the hybridization-washing condition employed in this study, signals were detected in some strains of Micromonospora and Dactylosporangium, i.e. M. purpurea ATCC 15835 and M. echinospora subsp. echinospora ATCC 15837 both of which produced gentamicins, $M$. zionensis IFO 14116 which produced sisomicin, and D. aurantiacum ATCC 23491.

\section{Discussion}

We have cloned a DNA fragment encoding sannamycin B-glycyltransferase (smsl3) using the self-cloning system of $S$. sannanensis. In both $S$. sannanensis and $S$. lividans carrying sms 13, fortimicin B was efficiently converted to fortimicin $A$ in spite of difference in structures between sannamycin $B$ and fortimicin B. This agrees with the result of bioconversion studies using the washed mycelia of 
Fig. 4. Fortimicin B to fortimicin A converting activity by the sms 13 gene product.

(a) (c); HPLC chromatograph of the bioconversion products of fortimicin B by the washed mycelia of $S$. sannanensis wild type (a), S. sannanensis SN13 (b), S. sannanensis SN13 (pSN13-1) (c). (d) (f); HPLC chromatograph of the bioconversion products of fortimicin B by the washed mycelia of $S$. lividans TK23 (pSN13-1-8T), control experiment without the substrate (d), with the substrate (e) and the converted products after alkaline treatment in $0.16 \mathrm{~N} \mathrm{NH}_{4} \mathrm{OH}$ (f).

(a)

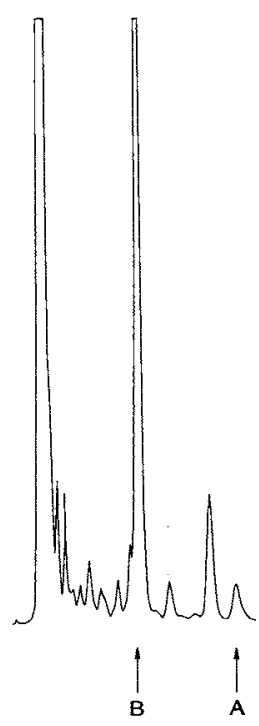

(d)

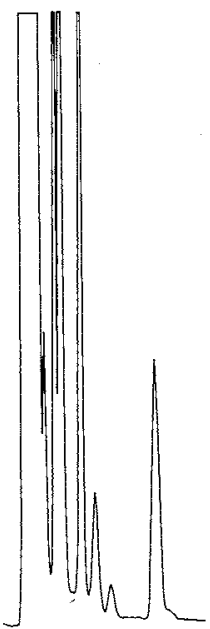

(b)

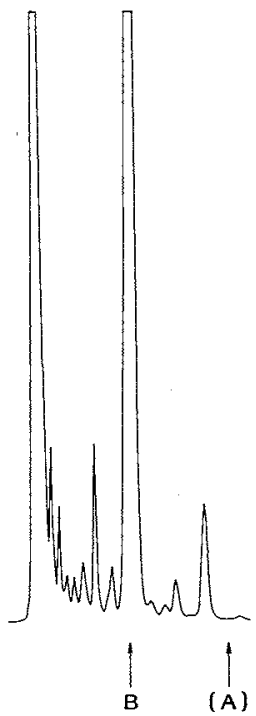

(c)

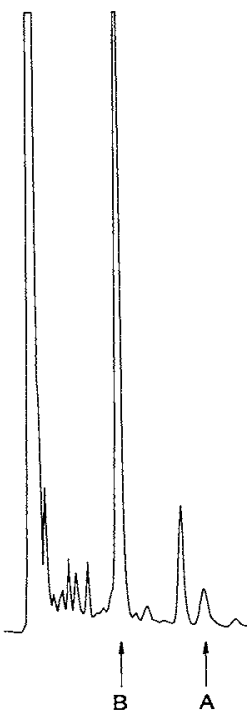

(f)

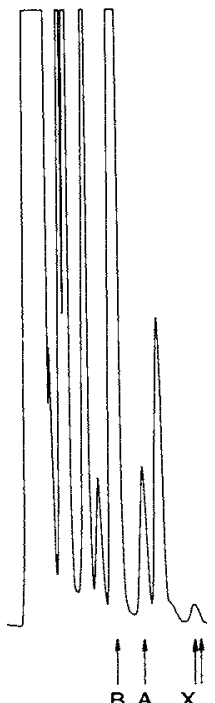

(FA)

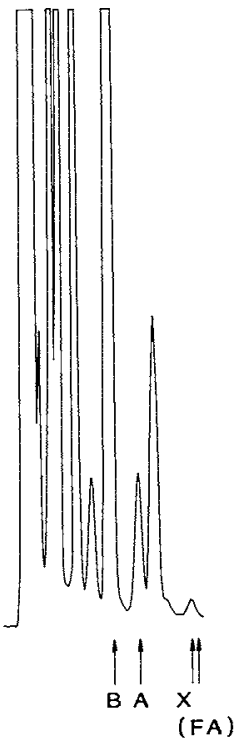

(a) $\sim$ (c) and (d) $\sim$ (f) were separated with $5.5 \%$ methanol and with $7.5 \%$ methanol, respectively. Positions of retention times of peaks, fortimicin $\mathrm{B}$, fortimicin $\mathrm{A}, \mathrm{N}$-formimidoylfortimicin $\mathrm{A}$ and the unknown products are indicated as vertical arrows with $\mathrm{B}, \mathrm{A},(\mathrm{FA})$ and $\mathrm{X}$, respectively. 
Fig. 5. Distribution of DNAs homologous to sms 13 .
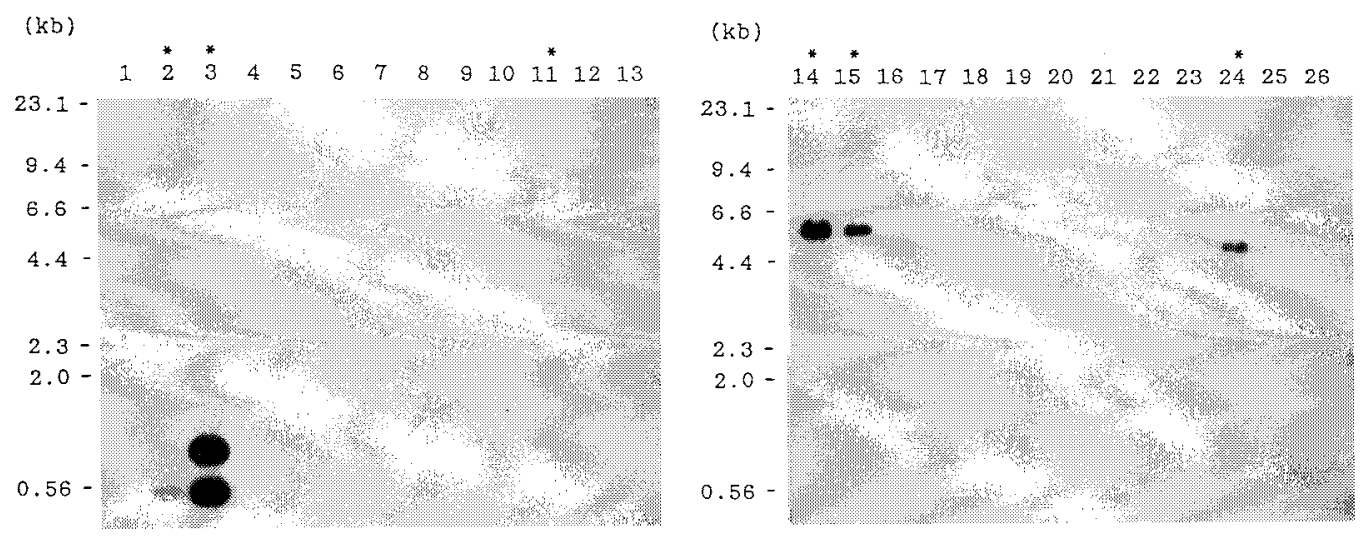

The $0.8 \mathrm{~kb}$ Sal $\mathrm{I}$ fragment within $s m s 13$ was used as probe (see Fig. 3). Total DNAs were digested with BamH I. Lanes are Streptomyces lividans TK23 (lane 1); Streptomyces tenjimariensis ATCC 31603 (istamycin producer) (lane 2); Streptomyces sannanensis IFO 14239 (sannamycin) (lane 3); Streptomyces fradiae ATCC 10745 (neomycin) (lane 4); Streptomyces griseus subsp. griseus (Waksman) (streptomycin) (lane 5); Streptomyces kasugaensis ATCC 15715 (kasugamycin) (lane 6); Streptomyces hygroscopicus subsp. hygroscopicus ATCC 27438 (hygromycin) (lane 7); Streptomyces kanamyceticus ATCC 12853 (kanamycin) (lane 8); Streptomyces ribosidificus ATCC 21294 (ribostamycin) (lane 9); Streptomyces tenebrarius IFO 13396 (nebramycin) (lane 10); Saccharopolyspora hirsuta ATCC 20501 (sporaricin) (lane 11); Saccharopolyspora hirsuta MK-220 (XK-220; a macrolide antibiotics) (lane 12); Saccharopolyspora hirsuta ATCC 27875 (lane 13); Micromonospora olivasterospora ATCC 21819 (fortimicin) (lane 14); Micromonospora sp. SF-2098 ATCC 31580 (SF-2052) (lane 15); Micromonospora purpurea ATCC 15385 (gentamicins) (lane 16); Micromonospora sagamiensis subsp. nonreducans ATCC 21803 (sagamicin and gentamicin Al) (lane 17); Micromonospora sagamiensis ATCC 21826 (sagamicin and gentamicin Al) (lane 18); Micromonospora echinospora subsp. echinospora ATCC 15837 (gentamicins) (lane 19); Micromonospora echinospora subsp. pallida ATCC 15838 (gentamicins) (lane 20); Micromonospora inyonensis ATCC 27600 (sisomicin) (lane 21); Micromonospora zionensis IFO 14116 (sisomicin) (lane 22); Micromonospora echinospora subsp. ferruginea ATCC 15836 (gentamicins) (lane 23); Dactylosporangium matsuzakiense ATCC 31570 (dactimicin) (lane 24); Dactylosporangium aurantiacum ATCC 23491 (lane 25); Dactylosporangizm variesporam (capreomycin) (lane 26). Asterisks indicate the producers of the fortimicin-group antibiotics.

S. sannanensis ${ }^{13)}$. Bioconversion of fortimicin B using S. lividans TK23 (pSN13-1-8T) confirmed that the cloned DNA fragments contained the structural gene of sannamycin B-glycyltransferase and not a regulatory gene.

Two different pathways have been postulated for the final stage of the biosynthesis of fotimicin A. In one, the final product, $N$-formimidoylfortimicin $\mathrm{A}$, is directly synthesized from fortimicin $\mathrm{B}$ by addition of $\mathrm{N}$-formimidoylglycine, and that fortimicin $\mathrm{A}$ is produced by a non-enzymatical decomposition of $N$-formimidoylfortimicin $\mathrm{A}^{14)}$. The other is that fortimicin $\mathrm{A}$ is synthesized from fortimicin $\mathbf{B}$ by addition of one molecule of glycine, and consequently $N$-formimidoylfortimicin $\mathrm{A}$ is synthesized by addition of a formimidoyl group to the glycine moiety of fortimicin $\mathrm{A}^{23)}$. Our results show the presence of a glycyltransferase directly converting fortimicin B to A in S. sannanensis; no activity converting fortimicin B to $N$-formimidoylfortimicin A was detected in S. lividans TK23 (pSN13-1-8T). The DNA fragment hybridizing with the sms 13 probe identified within the gene cluster for fortimicin A biosynthesis in $M$. olivasterospora (DAIRI et al.; in preparation) must encode fortimicin B-glycyltransferase. These results support the notion that the final steps of fortimicin A biosynthesis are fortimicin $B \rightarrow$ fortimicin $\mathrm{A} \rightarrow N$-formimidoylfortimicin A.

Sequences hybridizing to a DNA probe derived from the $s m s 13$ gene were found in all six producers of the fortimicin-group antibiotics. They are likely to be genes similar to that for sannamycin B-glycyltransferase responsible for glycine transfer to their corresponding precursors. This suggests that 
the sequences of the glycyltransferases are conserved among the producers of the fortimicin-group antibiotics. With respect to the common biosynthetic steps between $M$. olivasterospora and $S$. sannanensis and the sequence conservation of the biosynthetic genes among the producers of the fortimicin-group antibiotics ${ }^{13)}$, the biosynthetic genes might have evolved from a common set of ancestral genes and propagated beyond the genera.

In DNA hybridization studies using sms 13 , faint signals were detected in strains which produced the other aminoglycoside antibiotics, such as gentamicins and sisomicin. These signals could be due to similarity with $s m s 13$ or its flanking sequences. These strains are not known to produce any of the fortimicin-group antibiotics. Considering the structures of gentamicins and sisomicin, glycyltransferase activity would not be involved in their biosynthesis. This suggests that they have silent glycyltransferase genes which are not expressed under laboratory conditions, or that there may be some sequence relationships within the biosynthetic genes for aminoglycoside antibiotics. Further work is needed to determine the sequences of these related genes and the functions of the gene products.

\section{Acknowledgment}

We thank Ms. K. FUתWARA for her excellent technical assistance.

\section{References}

1) Malpartida, F.; S. E. Hallam, H. M. Kieser, H. Motamedi, C. R. Hutchinson, M. J. Butler, D. A. Sugden, M. Warren, C. MCKillop, C. R. Bailey, G. O. Humphreys \& D. A. Hopwood: Homology between Streptomyces genes coding for synthesis of different polyketides used to clone antibiotic synthesis genes. Nature 325: $818 \sim 821,1987$

2) Weigel, B. J.; S. G. Burgett, V. J. Chen, P. L. Skatrud, C. A. Frolik, S. W. Queener \& T. D. Ingolia: Cloning and expression in Escherichia coli of isopenicillin $\mathrm{N}$ synthetase genes from Streptomyces lipmanii and Aspergillus nidulans. J. Bacteriol. 170: 3817 3826, 1988

3) Leskiw, B. K.; Y. Aharonowitz, M. Mevarech, S. Wolfe, L. C. Vining, D. W. S. Westlake \& S. E. Jensen: Cloning and nucleotide sequence determination of the isopenicillin $\mathrm{N}$ synthetase gene from Streptomyces clavuligerus. Gene 62: 187 196, 1988

4) Schifman, D.; M. Mevarech, S. E. Jensen, G. Cohen \& Y. Aharonowitz: Cloning and comparative analysis of the gene coding for isopenicillin N synthetase in Streptomyces. Mol. Gen. Genet. 214: 562 569, 1988

5) Burnham, M. K. R.; A. J. Earl, J. H. Bull, D. J. Smith \& G. Turner (Beecham): DNA encoding ACV synthetase. Eur. Pat. Appl. 88311 655.0, Dec. 9, 1989

6) Nara, T.; M. Yamamoto, I. Kawamoto, K. Takayama, R. Okachi, S. Takasawa, T. Sato \& S. Sato: Fortimicins $\mathrm{A}$ and $\mathrm{B}$, new aminoglycoside antibiotics. I. Producing organism, fermentation and biological properties of fortimicins. J. Antibiotics 30: 533 540, 1977

7) Watanabe, I.; T. Deushi, T. Yamaguchi, K. Kamiya, M. Nakayama \& T. Mori: The structural elucidation of aminoglycoside antibiotics, sannamycins A and B. J. Antibiotics 32: 1066 1068, 1979

8) Okami, Y.; K. Hotta, M. Yoshida, D. IKeda, S. Kondo \& H. Umezawa: New aminoglycoside antibiotics, istamycins A and B. J. Antibiotics 32: 964 966, 1979

9) Deushi, T.; A. Iwasaki, K. Kamiya, T. Kunieda, T. Mizoguchi, M. Nakayama, H. Iroh, T. Mori \& T. Oda: A new broad-spectrum aminoglycoside antibiotic complex, sporaricin. I. Fermentation, isolation and characterization. J. Antibiotics 32: 173 179, 1979

10) Ohba, K.; T. Shomura, T. Tsuruoka, M. Kojima, S. Inoue \& T. Itoh (Meiji Seika): Production of antibiotics SF-2052. Jpn. Kokai 18600 ('81), Feb. 21, 1981

11) Inouye, S.; K. Ohba, T. Shomura, M. Kojima, T. Tsuruoka, J. Yoshida, N. Katō, M. Itō, S. Amano, S. Omoto, N. EZakı, T. Itō, T. NuDA \& K. WatanabE: A novel aminoglycoside antibiotic, substance SF-2052. J. Antibiotics 32: $1354 \sim 1356,1979$

12) Odakura, Y.; H. Kase, S. Itoh, S. Satoh, S. Takasawa, K. Takahashl, K. Shirahata \& K. Nakayama: Biosynthesis of astromicin and related antibiotics. II. Biosynthetic studies with blocked mutants of Micromonospora olivasterospora. J. Antibiotics 37: 1670 1680, 1984

13) Dairi, T. \& M. Hasegawa: Common biosynthetic feature of fortimicin-group antibiotics. J. Antibiotics 42: 934 943, 1989

14) HotTA, K.; M. Morioka \& Y. OKami: Biosynthetic similarity between Streptomyces tenjimariensis and Micromonospora olivasterospora which produce fortimicin-group antibiotics. J. Antibiotics 42: 745 751, 1989 
15) Ohta, T.; E. Hashimoto, T. Dairi \& M. Hasegawa: Construction and application of gene cloning system for Streptomyces sannanensis, a producer of fortimicin-group antibiotics. In Trends in Actinomycetology in Japan. Ed., Y. KoYama et al., pp. $101 \sim 102$, Society for Actinomycetes, 1989

16) OHTA, T.; E. Hashimoto \& M. Hasegawa: Characterization of sannamycin A-nonproducing mutants of Streptomyces sannanensis. J. Antibiotics 45: $289 \sim 291,1992$

17) Nagano, E.; M. Hasegawa \& I. Kawamoto (Kyowa Hakko): Novel cloning vectors. Jpn. Pat. 135031 ('88), June 1,1988

18) Chater, K. F.; D. A. Hopwood, T. Kieser \& C. J. Thompson: Gene cloning in Streptomyces. Curr. Top. Microbiol. Immunol. 96: 69 95, 1982

19) KIESER, T.: Factors affecting the isolation of CCCDNA from Streptomyces lividans and Escherichia coli. Plasmid 12: $19 \sim 36,1984$

20) Ohta, T. \& M. Hasegawa: Cloning and characterization of the self-defense gene of $S$. tenjimariensis and its distribution. In Trends in Actinomycetology in Japan. Ed., Y. Koyama et al., pp. 89 90, Society for Actinomycetes, 1989

21) ReED, K. C. \& D. A. MANN: Rapid transfer of DNA from agarose gels to nylon membranes. Nucleic Acids Res. 13: $7207 \sim 7220,1985$

22) Maniatis, T.; E. F. Fritsch \& J. SAmbrook: Biochemical techniques. In Molecular Cloning. Ed., T. Maniatis et al., pp. 436 478. Cold Spring Harbor Laboratory, 1982

23) DAIRI, T. \& M. HASEGAwa: Common feature beyond the generic difference of the biosynthesis of fortimicins and sannamycins. In Trends in Actinomycetology in Japan. Ed., Y. KoYAMA et al., pp. 65 68, Society for Actinomycetes, 1989 